\title{
Early Childhood Teachers Cooperation with Parents in Implementing Islamic Sex Education for Children
}

\author{
Erhamwilda $^{a}$, Asep Dudi Suhardini ${ }^{\mathrm{b}}$, Nurul Afrianti ${ }^{\mathrm{c}}$ \\ Education Faculty, Universitas Islam Bandung \\ Bandung, Indonesia \\ Corresponding e-mail: aerhamhoernis@gmail.com, basep.abushaffa@gmail.com, \\ cnurulafrianti28@gmail.com
}

\begin{abstract}
The purpose of this study is to obtain a picture of the cooperation program of early childhood education teachers with parents in implementing Islamic sex education. The study used the qualitative approach with descriptive method, and deep interview technique. A total of 12 teachers of Islamic Kindergarten (RA) in Cianjur, West Java became the subject of research. The results show that not every teacher makes efforts to collaborate with parents in Islamic sex education for early childhood. For teachers who implement cooperation with new parents, they are limited to the rules that need to be established for children, but there is no specific program of cooperation in Islamic sex education. The study recommends a cooperation program of RA teachers with parents in carrying out Islamic sex education including: (1) objectives; (2) material; (3) methods; (4) media, and (4) protection of children from sexual violence.
\end{abstract}

Keywords: $\quad$ cooperation- PAUD teachers, parents, sex education

\section{INTRODUCTION}

In Law No. 23 Year 2002 on Child Protection stated: "The child is a trust, and the gift of God Almighty, which in him is inherent dignity and honor as a whole person (part a.); Children are buds, potentials, and the younger generation of the ideals of the struggle of the nation to have a strategic role and have special features and traits that guarantee the continuity of the existence of nation and state in the future (part c) ...".

To implement the law, the effort to protect children from various acts of crime and violence is a shared responsibility that must be done by various parties, especially parents, teachers, communities where children live and live. Currently there are various threats to the safety of children biologically and psychologically to grow and develop in a healthy, smart, and good morals. Among the threats to child safety are predators of sexual violence that continue to search for victims.

The existence of international networks of sexual violence predators is a very dangerous threat for children. The number of predators recorded in the network reaches thousands in just +1 years (from 2016-2017). Metrotvnews.com (Thursday 16 March 2017 pk 06.35 wib) reported that "The Paedofil
Network Extends, Indonesia is considered to be a fertile field for the movement of the pedophiles. The same thing is said in The Jakarta Post "Indonesia, along with other Southeast Asian countries such as Combodia and Thai, has long been seen as a haven for pedophiles, including those coming from Western countries. In Marc, the was shocked when the Jakarta Police uncovered a closed Facebook group of some 7,000 members alleged to have shared child pornography since last year. Some of them, the police said, are believed to be foreigners (The Jakarta Post, Tuesday July 11, 2017: 1) [1]. The police also revealed that "after the arrest of four suspects from 11 national and international networks, there are still a number of potential suspects. Indonesia must be wary of being targeted by perpetrators of sexual violence against minors.

Early childhood is more prone to become the victim because they are still innocent, easily persuaded and very weak when threatened. On the other hand according to the level of development of early childhood, they want to know everything, including parts of his body. Meanwhile, according to S. Freud at the age of 3-6 years are at the age of phallic with the source of pleasure came from the genitals.

Ages 3-6 years most children living in educated environments have entered the play 
group and progress to kindergartens or Raudhatul Atfal (RA) or Early Childhood Education (PAUD) of its kind. While for children who do not go to kindergarten / early childhood has been playing and exploring in the environment outside, although it can happen otherwise for children who are only given gadgets / smartphones, games, or television as a friend and they will be busy with the consumption. This means that the child is no longer just hanging out and interacting in the house with his nearest parents or family but begins to interact with many people of different ages outside the home or otherwise interacts with the digital set of tools available to him.

Children who are lucky at this age are the ones who interact in educational nuance with parents, teachers as well as obtaining guidance and security guard from adults around him. In fact today many unlucky children, are just left alone, so that children can play anywhere, with anyone, escaped from the monitoring of parents and teachers, or on the other side of the child is also free to watch and see anything, not least games, gadgets / smartphones, videos, with pornographic contents belong to their parents or teenagers around them.

Erhamwilda, et al $(2015,2016)$ [2] study of early childhood victims of sexual violence, shows the daughters who are victims came from families who are often left their daughter to play alone or play with anyone outside the home. The data indicate that sexual violence can occur at home by close relatives, neighbors, at your siblings when your children visit, on your way home and go to pre-school institutions, in pre-school institutions, and in relatives' homes when the child is staying at the home of one close relative.

This fact shows that parents play a major role in the education, coaching and protection of children from various acts of sexual violence. On the other hand, Kindergarten / RA / PAUD teachers as professionals in helping children grow up become the next important personnel after parents in seeking the prevention and protection of children from acts of sexual violence in children. Therefore, the establishment of well-organized cooperation between teachers and parents in facing the threat of child sexual violence becomes very urgent. This research develops cooperation program of sex education for early age between teacher and parent. The program was created based on a study of empirical facts of cooperation that has been done by teachers of kindergarten / RA / PAUD in education, and theoretical studies.

\section{Parent-Teacher Partnership}

Parent-Teacher Partnership is not a new term. In 1988, Brofenbrenner (in Mawere, et al., 2015) [3] argued that, early childhood education programs need to involve parents and the social environment of children to be more effective and lasting. The partnership itself describes a cooperative relationship between parents and teachers. Each party has its own role. This cooperation aims at the welfare of children. Parents and teachers become co-workers in a joint effort to help children develop optimally.

Parental involvement in children's education can develop a good personality and affect the overall success of children's education in the future (Ali, et al., 2014) [4]. Moreover, a study reports on the impact of parenting education programs involving 1400 participants for up to 25 years. These publicly funded interventions start from the preschool period up to 6 years later. Compared to the control group, the group receiving the intervention are proved to have higher educational attainment, income, and socioeconomic status, as well as lower levels of court involvement and use of substances (Reynolds, et al., 2011) [5]. This proves that the role of parents and early childhood education has a strong and lasting impact for several years, so that the role of parents cannot be separated in the early childhood education process.

Building cooperation between parents and teachers is not always easy. Every parent has a different personality, resulting in different reactions between one parent and the other. To build trust, the first impression plays a very important role. Therefore, teachers need preparation to deal with parents and establish good communication with them (Loughran, 2008) [6].

Good cooperation relations involve goodwill, openness, mutual respect, sympathy, honesty and wisdom. The effectiveness of cooperation between parents and teachers depends on both sides, how they communicate, create a comfortable and peaceful atmosphere, eliminate negative prejudices, be able to accept criticism, and be open to new ideas (Cooperation Between School and Parents, 2014) [7].

Loughran (2008) [6] explains, there are some things that need to be done to achieve good communication with parents namely: 
1) Communicate succinctly and clearly. Organize your thoughts ahead of time, review written messages.

2) Make clear to each one that he or she is respected and is or her participation is encouraged.

3) $\mathrm{Be}$ flexible, encouraging working parents to participate actively and be involved when and where possible.

Furthermore, with the formation of trust and mutual respect, teachers can provide home education advice, so that what is learned in school will be strengthened when parents spend time with children at home, and vice versa. Thus education at school and at home will be well connected.

\section{Tools Used for Cooperation with Parents}

There are several things that can be used as a tool to build cooperation with parents (Cooperation Between School and Parents, 2014) [7], including:

1) Parent -teacher meetings, organized 4-6 times a year, whose aim is to discuss various organizational matters concerning the class, students' school achievements and difficulties which teachers encounter in their work;

2) Social meetings, organised on the occasion of celebrations and class or school events enabling parents a better understanding of the atmosphere prevailing at school. Meetings of the parent class or school council, usually taking place while organizing various school and class events.

3) Meeting with an expert, held with the participation of a specially invited person, giving the parents help in matters beyond the professional competence of the class teacher/tutor, often taking the form of:

a. meetings concerning educational problems, in which all the students' parents can take part,

b. parent training meetings in form of conferences or lectures held during parent-teacher meetings.

4) Individual forms of cooperation between teachers and parents complement and enrich their collective communication. These include:
a. monthly
parent-teacher consultations, during which the parents have an opportunity to familiarize themselves with the

requirements and expectations of teachers and the educational situation of their child;

b. home visits, whose aim is closer and direct knowledge about the conditions in which students live and establishing personal contacts with all members of the family;

c. written communication via:

i. student's diary, which is primarily used to inform parents about the child's marks;

ii. letters to parents, which may be:

a)open letters, concerning education;

b) letters for parents of individual students. Written communication with parents should: reflect mutual respect, contain specific information written in plain language, cover all the important information, not just the negative, be neatly written, and be confidential if it contains content intended only for adults.

d. written reports of students' behaviour and academic achievements are used mostly during parent-teacher meetings, (these are pre-prepared cards with marks in all subjects including a behaviour mark)

e. telephone calls during which information and advice concerning the student's academic progress and behaviour is given.

\section{Difficulties in Home-School Cooperation}

According to Eldridge (2001, in Mawere, 2015:1546) [3], working with parents in Early Childhood Development can be one of the teacher"es most satisfying responsibilities or can be one of the most frustrating. Usually it is both.

The Teachers Szybinski High School and Psychologists from the Psychological and Pedagogical Counseling Center in Cieszyn summarizes some of the difficulties that may arise in the parent and teacher co-operation process (Cooperation Between School and 
Parents, 2014) [7]. In a nutshell, it's in the following table:

\begin{tabular}{|c|c|}
\hline Teachers & Parents \\
\hline Lack of time & Lack of time \\
\hline $\begin{array}{l}\text { A feeling of not being } \\
\text { listened to by the other side }\end{array}$ & $\begin{array}{l}\text { A feeling of not being } \\
\text { listened to by the other } \\
\text { side }\end{array}$ \\
\hline $\begin{array}{l}\text { Doubt that a conversation } \\
\text { might change anything }\end{array}$ & $\begin{array}{l}\text { Doubt that a conversation } \\
\text { might change anything }\end{array}$ \\
\hline $\begin{array}{l}\text { A sense of lack of real } \\
\text { influence on the behaviour } \\
\text { of parents towards their } \\
\text { children }\end{array}$ & $\begin{array}{l}\text { Fear that a conversation } \\
\text { with the teacher may have } \\
\text { a negative impact on the } \\
\text { treatment of their child. } \\
\text { Lack of trust }\end{array}$ \\
\hline $\begin{array}{l}\text { Their own or other } \\
\text { teachers' previous } \\
\text { experience indicating } \\
\text { absence of effects of } \\
\text { cooperation with the } \\
\text { parents or the parents' } \\
\text { underestimating of the } \\
\text { efforts undertaken by the } \\
\text { teacher }\end{array}$ & $\begin{array}{l}\text { No real sense of support } \\
\text { from the teacher }\end{array}$ \\
\hline $\begin{array}{l}\text { The feeling that the } \\
\text { problem lies not in the } \\
\text { pupil, but the family and } \\
\text { the teacher is not able to } \\
\text { change the whole complex } \\
\text { situation }\end{array}$ & $\begin{array}{l}\text { Fear of hearing " bad news } \\
" \text { about the child, thereby } \\
\text { also of lowering their value } \\
\text { as parents }\end{array}$ \\
\hline
\end{tabular}

Addressing these problems is not only a teacher's job, it is also a parent's job. Therefore, there are some things that teachers, parents, and parents and teachers need to do (Cooperation Between School and Parents, 2014) [7]. Among others are:

Teacher:

1) Prepare for the meeting-set the time, place and the purpose (what you want to achieve, try to anticipate difficulties, to be able to counteract them, be positive)

2) Instead of starting with saying what is wrong (a students have not done their homework), Start with what is good ( I like Jurek's sense of humour)

3) Instead of telling what the student did not do (he was daydreaming during lessons, he has not learned the multiplication table, ...) describe what the child should do (students who have been ill have to catch up on schoolwork)

4) Instead of saying negative things about the student and loosing faith in his success (well he is not Einstein...), end the meeting with a positive statement that the parent may repeat the student (please tell Andrew that I Parents:

\begin{tabular}{|c|c|}
\hline Fear of public performance & $\begin{array}{l}\text { Escape from taking on } \\
\text { (unconsciously) the role of } \\
\text { the student -defenseless } \\
\text { against the authority of the } \\
\text { teacher ( behaviour as in } \\
\text { the childhood: parents } \\
\text { forget that they are adults). }\end{array}$ \\
\hline $\begin{array}{l}\text { Objective difficulties in the } \\
\text { organization of meetings, } \\
\text { such as: lack of time and } \\
\text { space for quiet } \\
\text { conversation, etc }\end{array}$ & $\begin{array}{l}\text { Not feeling welcome, } \\
\text { teachers have to (not want) } \\
\text { to organise a meeting, time } \\
\text { pressure, poor organisation } \\
\text { of the meetings }\end{array}$ \\
\hline \multirow{3}{*}{$\begin{array}{l}\text { Burnout, aversion to } \\
\text { communicating with the } \\
\text { so-called "difficult } \\
\text { parents" because of the } \\
\text { emotional costs of this type } \\
\text { of relationships. }\end{array}$} & $\begin{array}{l}\text { No sense of the need for } \\
\text { the real involvement in the } \\
\text { school matters }\end{array}$ \\
\hline & $\begin{array}{l}\text { Parents' negative } \\
\text { experiences -decisions in } \\
\text { relation to their children } \\
\text { are made arbitrarily, } \\
\text { without their participation } \\
\text { or asking for their opinion }\end{array}$ \\
\hline & $\begin{array}{l}\text { Lack of parents' } \\
\text { integration, strangers have } \\
\text { problems working for the } \\
\text { common goal }\end{array}$ \\
\hline
\end{tabular}

1) Instead of hiding important information (my son spends four hours in front of his computer) provide information relevant to the case (because of that he is too tired to do his homework)

2) After the meeting do not forget about the arrangements you discussed with the teacher, act according to the plan (sisters help each other and get better marks, your husband has had more time recently, so he has been helping his son with homework, Bartek no longer spends so much time in front of the computer.)

\section{Parent and teacher:}

1) Instead of giving each other advice (you and your wife should ..., teachers should not you give so much material for reading), describe what is happening at home and at school, what brings good results (I noticed that after a break my son has more energy, he works better when he makes a break every 15 minutes.)

2) Agree on a common plan of action (e.g. the teacher will ask one of the students to help the child with mathematics, the parent will make sure that their child does not spend so much time in front of TV)

\section{Islamic Sex Education}


Clara Kriswanto, in Moh Roqib (2008: 67) [8] states that sex education for children aged $0-5$ years can be implemented with the following techniques or strategies.

1) Help the child to feel comfortable with his body.

2) Giving a touch and hug to the child so that they feel the affection of their parents sincerely.

3) Helping children understand the different behaviors that are allowed and which should not be done in public such as the finished child bathing should wear the clothes back in the bathroom or in the room. Children are told about personal things, not to be touched, and seen by others.

4) Teach children to know the difference in male and female anatomy

5) Provide an explanation of the process of body development such as pregnancy and childbirth in simple sentences, how the baby can be in maternal womb according to the child's cognitive level. Not allowed to lie to children like "sister coming from the sky or brought birds".

6) Provide an understanding of the function of the limbs naturally which is able to avoid the feeling of shame and guilt over the form and function of his own body.

7) Teach children to know the right names on every part of the body and its functions.

8) Helping children understand personal concepts and teach them when the sex talk is private.

9) Providing support and conducive atmosphere so that children want to consult parents for any questions about sex.

10) Needs to be added, the technique of sex education by giving understanding to the child about the composition of the family (nasab) so as to understand the social structure and religious teachings associated with the association of men and women. When the child is able to reason with the structure, parents can relate it to the fiqh lesson.

11) Familiarize with clothes that match their gender in their daily life and also when performing prayers will make it easier for children to understand and respect their limbs.
Ulwan (1999) as cited by Erhamwilda (2015: 113-114; 2016: 3-4) [9] [10] said that: "One of the rules behave very considered on Islam is moral association betwen men and women has been started at an ealy age. Islam provides sex education by instilling ethics through different treatment and different rules between boys and girls from infancy to adulthood. Here are some essential things in sex education:

a. Maintain the views of children by teaching ethics is requesting permission to enter the room of parents in three circumstances, namely: before the prayer of dawn, the time of day when ordinary parents undress or rest, and after the evening prayer based on the Quran (Surah AnNur: 58-59);

b. To teach boys and girls with genitalia restrictions that may be viewed and cannot be seen according to age one's development. For the children of men and women under the age of 4 years has not been required to cover the genitals, but accustoming early childhood to close the genitals is better. For children over 4 years of age they have to cover the private parts (genitalia), rectum, and surrounding areas;

c. Teaches different clothes for boys and girls, where girls' clothing covering most part of body, while boys may just need to cover from the abdomen to the knee;

d. Regulate the relationship between male and fellow male, as well as between female and fellow female, it's prohibited to look at each other genitals. The older the children, there will be stricter rules to protect the child.

e. Prevent children from sexual stimuli by having two kind of responsibilities: internal factors oversight responsibilities, and external oversight responsibility.

Oversight responsibility of internal factors, are:

a. Avoiding the boys over the age of 9 years to look at women with jewelry or clothing that gives sexual stimulate, and prohibits the boy entered the room of girls;

b. Boys and girls over ten years old should be have their room separated, 
and fellow boys should not sleep under one blanket in a cypress bed, as well as fellow girls should not be in same blanket and bed;

c. Children to be taught ethics of viewing from an early age, with ageappropriate boundaries for both children and adult, and also for both same-sex or opposite sex.

d. To prevent children from viewing images that stimulate, films/ soap opera that promoting free sex through television, mobile phones and other media;

e. Preventing child and their friends to enjoy nude pictures, porn magazines, , obscene stories and erotic songs, or other medias that can make a sexual stimulation.

\section{METHODOLOGY}

This study used a qualitative approach, because it wants to obtain comprehensive information to understand the complexities of human interaction. The methode of this study are decriptive. Data collection techniques are in-depth interview. The data sources are these educators from Islamic early childhood school (Radhatul At'fal/RA). The research takes place in the Cianjur, West Java. The research methods is chosen in accordance with the purpose of the study is to describe the partnership parents and teachers of RA in Islamic sexs education. In this research these are 12 teacher had participate as subject. The sample was taken purposively, ie RA teachers who have been given socialization about Islamic sex education for early childhood. The data analysis technique is inductive/qualitative, and the results further emphasize the significance. Test the validity of the data is done by triangulation between what is submitted by teachers, parents, and peer teachers..

\section{RESULTS AND DISCUSSION}

Based on in-depth interviews conducted on the teachers, then the form of cooperation that teachers do with parents in Islamic sex education can be described in the following table:
Table 1. Summary of interview with ra cianjur teacher

\begin{tabular}{|c|c|c|c|c|}
\hline No & $\begin{array}{l}\text { Responde } \\
\text { nt Initial }\end{array}$ & $\begin{array}{c}\text { Cooperation } \\
\text { Activity }\end{array}$ & $\begin{array}{l}\text { Hope in } \\
\text { cooperation }\end{array}$ & $\begin{array}{c}\text { Obstacl } \\
\text { es in } \\
\text { coopera } \\
\text { tion } \\
\end{array}$ \\
\hline 1. & EV & $\begin{array}{l}\text { No cooperation yet. } \\
\text { Educational } \\
\text { programs for parents } \\
\text { related to sex } \\
\text { education for } \\
\text { children have not } \\
\text { been done directly } \\
\text { and are still in the } \\
\text { form of inserting } \\
\text { material on RPPH. }\end{array}$ & $\begin{array}{c}\text { Before } \\
\text { getting } \\
\text { training in } \\
\text { sex } \\
\text { education } \\
\text { for early } \\
\text { childhood, } \\
\text { have not } \\
\text { thought of } \\
\text { cooperation, } \\
\text { with parents } \\
\text { in sex } \\
\text { education. } \\
\text { Plan to } \\
\text { make } \\
\text { cooperation } \\
\text { in the form } \\
\text { of parenting } \\
\text { sex } \\
\text { education } \\
\end{array}$ & $\begin{array}{c}\text { Many } \\
\text { parents } \\
\text { are } \\
\text { difficult } \\
\text { to work } \\
\text { together } \\
\text { because } \\
\text { of busy } \\
\text { work } \\
\text { and } \\
\text { more } \\
\text { involvi } \\
\text { ng other } \\
\text { family } \\
\text { member } \\
\text { s like } \\
\text { grandm } \\
\text { other }\end{array}$ \\
\hline 2. & $\mathrm{Rn}$ & $\begin{array}{l}\text { There is no full } \\
\text { cooperation with the } \\
\text { parents, still a case } \\
\text { of per-case found }\end{array}$ & $\begin{array}{l}\text { Respondent } \\
\mathrm{s} \text { felt it was } \\
\text { necessary to } \\
\text { periodically } \\
\text { do parenting } \\
\text { with parents } \\
\text { in } \\
\text { discussing } \\
\text { cases of } \\
\text { child abuse, } \\
\text { crime mode } \\
\text { and } \\
\text { prevention } \\
\text { that parents } \\
\text { can do }\end{array}$ & $\begin{array}{c}\text { Some } \\
\text { parents } \\
\text { are } \\
\text { quite } \\
\text { coopera } \\
\text { tive but } \\
\text { there } \\
\text { are also } \\
\text { parents } \\
\text { who are } \\
\text { not } \\
\text { coopera } \\
\text { tive and } \\
\text { view } \\
\text { sex } \\
\text { educati } \\
\text { on is } \\
\text { still a } \\
\text { taboo to } \\
\text { be } \\
\text { convey } \\
\text { ed to } \\
\text { children }\end{array}$ \\
\hline 3. & Yy & $\begin{array}{l}\text { There is no co- } \\
\text { operation with } \\
\text { parents relating to } \\
\text { sex education for } \\
\text { children in } \\
\text { particular. } \\
\text { Cooperation with } \\
\text { parents is still in the } \\
\text { form of general } \\
\text { matters relating to } \\
\text { the development of } \\
\text { children in school }\end{array}$ & $\begin{array}{l}\text { There is no } \\
\text { special } \\
\text { expectation, } \\
\text { because feel } \\
\text { have } \\
\text { applied sex } \\
\text { education to } \\
\text { child that is } \\
\text { by using } \\
\text { uniform } \\
\text { covering the } \\
\text { aurat }\end{array}$ & 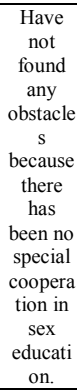 \\
\hline 4. & Ww & $\begin{array}{l}\text { There is no } \\
\text { cooperation with } \\
\text { parents, it still } \\
\text { revolves around the } \\
\text { problems of children } \\
\text { in the classroom, } \\
\text { and even then in } \\
\text { informal meetings. } \\
\text { There's just a chat in } \\
\text { the meeting with the } \\
\text { parents, so the girls } \\
\text { use shorts or longs } \\
\text { before short or long } \\
\text { skirts. }\end{array}$ & $\begin{array}{c}\text { After } \\
\text { getting } \\
\text { training on } \\
\text { sex } \\
\text { education } \\
\text { for early } \\
\text { childhood, } \\
\text { the school } \\
\text { considers } \\
\text { the need for } \\
\text { education } \\
\text { for parents } \\
\text { in parenting } \\
\text { activities to } \\
\text { prevent the } \\
\text { occurrence } \\
\text { of sexual } \\
\text { violence in } \\
\text { children } \\
\text { Sex } \\
\text { education } \\
\text { wants to be } \\
\text { applied } \\
\end{array}$ & $\begin{array}{c}\text { Some } \\
\text { parents } \\
\text { still feel } \\
\text { no need } \\
\text { to apply } \\
\text { sex } \\
\text { educati } \\
\text { on to } \\
\text { children }\end{array}$ \\
\hline
\end{tabular}




\begin{tabular}{|c|c|c|c|c|}
\hline 5. & Va & $\begin{array}{l}\text { Cooperation with } \\
\text { parents still in the } \\
\text { form of matters } \\
\text { relating to aspects of } \\
\text { child development in } \\
\text { general in terms of } \\
\text { cognitive, physical } \\
\text { motor, language, } \\
\text { social and } \\
\text { emotional. } \\
\text { Specialized } \\
\text { collaboration on sex } \\
\text { education in children } \\
\text { does not yet exist. }\end{array}$ & $\begin{array}{l}\text { After the } \\
\text { training, } \\
\text { respondents } \\
\text { summoned } \\
\text { parents and } \\
\text { were given } \\
\text { information } \\
\text { related to } \\
\text { cases of } \\
\text { sexual } \\
\text { violence in } \\
\text { children. } \\
\text { His } \\
\text { expectations } \\
\text { are followed } \\
\text { up with } \\
\text { experts }\end{array}$ & $\begin{array}{c}\text { There is } \\
\text { no } \\
\text { obstacle } \\
\text { because } \\
\text { some } \\
\text { parents } \\
\text { want to } \\
\text { get } \\
\text { more } \\
\text { informa } \\
\text { tion to } \\
\text { prevent } \\
\text { the } \\
\text { occurre } \\
\text { nce of } \\
\text { sexual } \\
\text { violenc } \\
\text { e in } \\
\text { children }\end{array}$ \\
\hline 6. & St & $\begin{array}{c}\text { Particular } \\
\text { cooperation is not } \\
\text { done with parents. } \\
\text { Cooperation with } \\
\text { parents still revolves } \\
\text { around issues of } \\
\text { child growth and } \\
\text { school barriers in } \\
\text { children. }\end{array}$ & $\begin{array}{l}\text { In the future } \\
\text { there is } \\
\text { cooperation } \\
\text { with parents } \\
\text { to provide } \\
\text { education } \\
\text { on the } \\
\text { prevention } \\
\text { of sexual } \\
\text { violence } \\
\text { against } \\
\text { children } \\
\end{array}$ & $\begin{array}{l}\text { Not yet } \\
\text { known } \\
\text { barriers } \\
\text { in } \\
\text { coopera } \\
\text { tion for } \\
\text { sex } \\
\text { educati } \\
\text { on }\end{array}$ \\
\hline 7. & $\mathrm{Ei}$ & $\begin{array}{l}\text { There is no } \\
\text { cooperation with } \\
\text { parents discussing } \\
\text { about sex education } \\
\text { for children } \\
\text { Sex education in } \\
\text { children is still in the } \\
\text { form of entering the } \\
\text { theme my body has } \\
\text { not made a special } \\
\text { RPP about sex } \\
\text { education } \\
\end{array}$ & $\begin{array}{c}\text { Respondent } \\
\mathrm{s} \text { considered } \\
\text { the need to } \\
\text { do parenting } \\
\text { that } \\
\text { discusses } \\
\text { the } \\
\text { prevention } \\
\text { of sexual } \\
\text { violence in } \\
\text { children }\end{array}$ & $\begin{array}{c}\text { Unkno } \\
\text { wn }\end{array}$ \\
\hline 8. & ApS & $\begin{array}{l}\text { Cooperation has not } \\
\text { been done yet, as } \\
\text { parents are aware of } \\
\text { the importance of } \\
\text { sex education for } \\
\text { children after being } \\
\text { informed by teachers } \\
\text { There was once a } \\
\text { parenting activity, } \\
\text { only contains ways } \\
\text { to educate children } \\
\text { especially who can } \\
\text { not study. }\end{array}$ & $\begin{array}{l}\text { It is } \\
\text { important to } \\
\text { give an } \\
\text { expert's } \\
\text { explanation } \\
\text { for parents } \\
\text { regarding } \\
\text { sex } \\
\text { education } \\
\text { for children, } \\
\text { as teachers } \\
\text { feel } \\
\text { incompetent } \\
\text {. Next } \\
\text { Will } \\
\text { cooperate } \\
\text { with parents } \\
\text { in } \\
\text { implementi } \\
\text { ng sex } \\
\text { education } \\
\text { for children }\end{array}$ & $\begin{array}{c}\text { Cooper } \\
\text { ation } \\
\text { with } \\
\text { parents } \\
\text { is still } \\
\text { much } \\
\text { constrai } \\
\text { ned by } \\
\text { the } \\
\text { attitude } \\
\text { of } \\
\text { parents } \\
\text { who are } \\
\text { apatheti } \\
\text { c with } \\
\text { sex } \\
\text { educati } \\
\text { on. } \\
\text { There } \\
\text { are } \\
\text { even } \\
\text { parents } \\
\text { who are } \\
\text { indiffer } \\
\text { ent to } \\
\text { the way } \\
\text { they } \\
\text { dress } \\
\text { themsel } \\
\text { ves and } \\
\text { tend to } \\
\text { show } \\
\text { aurat. } \\
\text { There } \\
\text { are also } \\
\text { parents } \\
\text { who } \\
\text { work in } \\
\text { nightclu } \\
\text { bs }\end{array}$ \\
\hline 9. & $\mathrm{Na}$ & $\begin{array}{l}\text { In particular there is } \\
\text { no cooperation with } \\
\text { parents about sex } \\
\text { education. Most } \\
\text { parents still } \\
\text { emphasize the } \\
\text { ability to read, write } \\
\text { and count the } \\
\text { children only }\end{array}$ & $\begin{array}{l}\text { Feel the } \\
\text { need to held } \\
\text { parenting } \\
\text { training but } \\
\text { with expert } \\
\text { speakers } \\
\text { from the } \\
\text { College }\end{array}$ & $\begin{array}{c}\text { Cooper } \\
\text { ation } \\
\text { with } \\
\text { parents } \\
\text { is still } \\
\text { constrai } \\
\text { ned by } \\
\text { the } \\
\text { econom } \\
\text { ic } \\
\end{array}$ \\
\hline
\end{tabular}

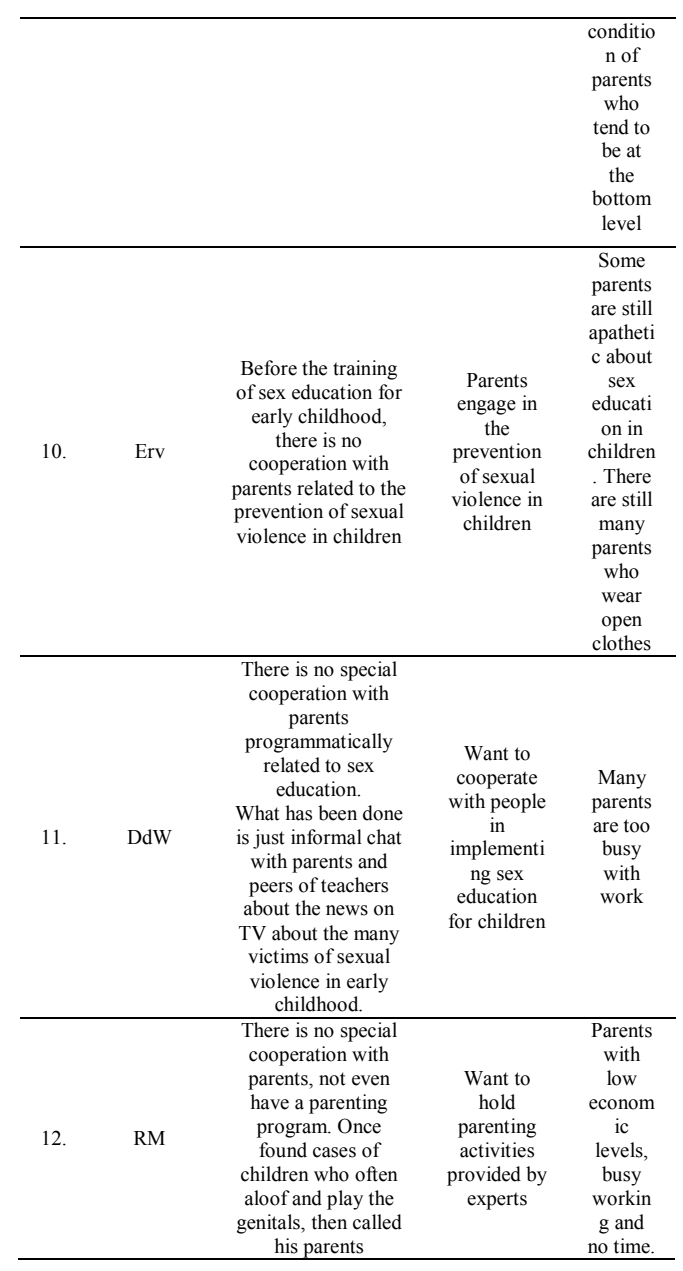

Based on the above description, it can be seen that: all RA teachers $(100 \%)$ stated that they have not made programmed cooperation with parents in implementing sex education for children. The new teacher realizes the importance of sex education for children after getting training on the model of Islamic sex education for young children.

The collaboration that has been done by 5 teachers ( $45 \%$ of respondents) is limited to discussing problems of child development and learning in the classroom, and if there are cases that are striking on the attitude and behavior of the child, but not programmed or only incidental nature. This means that parenting programs and cooperation with parents have not yet become a mandatory program. While the interview is also known that if teachers find children who behave differently, referred to as irregularities, but it could be just part of behavior change because it wants to recognize the body.

Teachers' expectation of the need to establish cooperation with parents in child sex education, comes after teachers are trained on the model of Islamic sex education with a 
mediated learning experience that researchers do. Almost all RA teachers who become respondents consider it important to hold parenting activities to prevent children from becoming victims of sexual violence, but there are still teachers who do not express congruously the desire to cooperate, because it has applied the rules of dress that cover the aurat. This view is actually appropriate but Islamic sex education is not just a matter of dress ethics.

Obstacles that teachers feel when building cooperation with parents are: only a few parents who come to attend school, because busy work. Especially parents with weak economic status, feel entrusted children in school, then all kinds of related education and child development submitted to the teacher. In addition, many parents are still apathetic to the education of children in school, only concerned with the ability of children in reading and writing. It is also a fact of a lack of parental understanding of child growth and the purpose of schooling in RA.

Field facts require the formulation of cooperation program in sex education for early childhood, to prevent child become victim of sexual violence. This program is important, because field facts indicate that acts of sexual violence in early childhood often occur in the home environment, in the family home, the playing environment of the family, close neighbors or people who are known children, as well as home trips to pre-school institutions. Thus the involvement of parents in protecting and building the independence of children to protect themselves from sexual violence, is very urgent. Parents should ideally know the purpose of sex education, what values should be invested in children in sex education, what methods and approaches can be used. This is in line with Brofenbrenner (in Mawere, et al., 2015) argues that, early childhood education programs need to involve parents and the child's social environment to be more effective and lasting. Education in question is certainly not only academic but also the moral development of religion, socio-emotional, and other aspects of personality. Parental involvement in children's education can develop a good personality and affect the overall success of children's education in the future (Ali, et al., 2014)

Building the parent-teacher cooperation in sex education is characterized by two important things: building an open communication between the two, as well as building awareness of parents to engage directly in sex education. For that parents need to have knowledge, attitudes, and skills in implementing Islamic sex education at home, on the other hand teachers implement sex education through learning in school. Teachers also play a key role in bridging parents' understanding of sex education.

Observing obstacles felt by RA teachers to build cooperation with parents is difficult to communicate with parents, on the other hand teachers still need expert help in communicating Islamic sex education to parents then the cooperation steps that can be done by teachers are: (1) At the beginning of acceptance Student teachers make a commitment to collaborate with parents for successful child education; (2) Developing school programs, including parenting programs; (3) Delivering the educational objectives in the RA in general and the special purpose of child protection from acts of violence; (4) delivering school programs and value content to be invested in children, including values related to sex education; (5) clear division of roles between parents and teachers in the development of all aspects of the child's personality and in sex education; (6) cooperation with experts in the delivery of sex education approaches for children for teachers and parents of children; (7) make a commitment to deal together if a case is found or a deviation of behavior in a child; (8) Building cooperation with psychologists and P2TP2A if any child becomes a victim of sexual violence. (9) Discusses the child's issues, including in the protection of children in the first quarter, second quarter, and third quarter. In every meeting with parents, it is organized through a family-friendly, comfortable, flexible, and fun atmosphere

\section{CONCLUSION}

In order to prevent children from becoming victims of sexual violence, building cooperation between teachers and parents is a necessity. Cooperation program can be made in the form of meeting time minimum 3 times a year. For the implementation of cooperation in sex education for early childhood teachers need to build a comfortable open communication with parents and build awareness of parents to engage directly in the education and development of children by making a commitment from the beginning. Teachers need to help bring in experts to equate perceptions in the approach of sex 
education and Islamic values that need to be instilled to be a reflection in attitude and behavior for young children.

\section{RECOMMENDATION}

The cooperation program of sex education between teachers and parents contains a shared commitment includes

1) The purpose of education Sex is a child capable of behaving as men and women according to Islamic values by becoming his holiness

2) Sex education materials for early childhood: keeping a child's view of pornographic good through spectacle, $\mathrm{HP}$, and direct person behavior in the environment; Safe and beautiful and beautiful girls and boys clothing; Toilet training; Self-sufficiency bathing and dressing; Sleep independence, maintaining the privacy of his body, refusing when invited by strangers, telling parents and teachers for various activities.

3) Sex education methods and media: Sex education is given through play situations and storytelling using the media images, dolls, natural centers, puppet play.

4) Child protection efforts of sexual acts committed by protecting and supervising together among parents in the neighborhood and teachers in the school environment, as well as cooperation with families and communities around schools and homes.

\section{REFERENCES}

[1] The Jakarta Post. (2017). RI to Keep Child Sex Offenders at Bay. Tuesday July 11-page 1.

[2] Erhamwilda \& Nurul Afrianti. (2016). Sex Education As A Protection For Early Age Girl From Sexual Abuse. Programme Book and Abstract. 2st International Conference on ASEAN Women. Sabah Kinabalu: UUM; Unisba; UCSF; UMS.

[3] Mawere, V. H., Thomas, K. T., \& Nyaruwata, L.T. (2015). An Evaluation of Parental Involvement in ECD Programme: A case Study of Primary School in Kuwadzana Suburb in Zimbabwe. Global Journal of Advanced Research. 2. 15451556.

[4] Ali, Arshad., Rahman, Abdur., \& Zeb, Alam. (2014). Family Involvement and Its Impact on Students' Achievement. Journal of Applied Environmental And Biological Sciences. 4. 496-500.

[5] Reynolds, A. J., Temple, J. A., Ou, SuhRuu., Arteaga, I. A., \& White, Barry A. B. (2011). School-Based Early Childhood Education and Age-28 Well-Being; Effects by Timing, Dosage, and Subgroups. Science. 333. 360-364.

[6] Loughran, S. B. (2008). The Importance of Teacher/Parent Partnerships: Preparing PreService and In-Service Teachers. Journal of College Teaching \& Learning. 5. 35-38.

[7] Cooperation between school and parents. (2014) Supporting the educational process: A guidebook for schools and parents. Project Comenius Regio; Life Long learning Programe. Tersedia On line: http://www.szybinski.cieszyn.pl. Down Load : 29 Juli 2017. 12.40.

[8] Moh. Roqib. (2008). INSANIA. Jurnal Pemikiran Alternatif Pendidikan. P3M STAIN Purwokerto. Vol. 13. No. 2. MeiAgs 2008. 271-286.

[9] Erhamwilda. (2015). Hypothetical Model of Sex Education For Early Childhood With Adaptive Mediated Learning Experience. Proceeding International Conference Of All Care For Children on Early Childhood Development (ICACCECD). Surabaya: PGPAUD Unesa and ARNEC-Indonesia.

[10] Erhamwilda \& Nurul Afrianti. (2015). Analysis on Early Childhood Sexual Abuse and The Implications in Islamic Education. Jurnal Pendidikan Islam.Vol. 2, Number 1, December 2015 M/1437 H. Bandung: The Faculty Of Tarbiyah And Teacher Training State Islamic University (UIN Sunan Gunung Djatu Bandung in Collaboration Association Of Indonesian Islamic Education Scholars. 